\title{
Applications in medicine: joint health
}

\section{Ezequiel R. Coscueta}

María Emilia Brassesco

Patrícia Batista

Sandra Borges

Manuela Pintado

Universidade Católica Portuguesa, CBQF-Centro de Biotecnologia e Química Fina-Laboratório Associado, Escola Superior de Biotecnologia, Porto, Portugal

\subsection{Introduction}

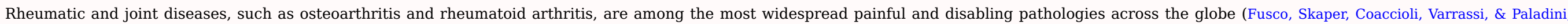

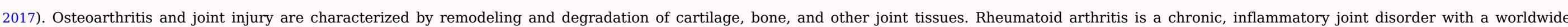

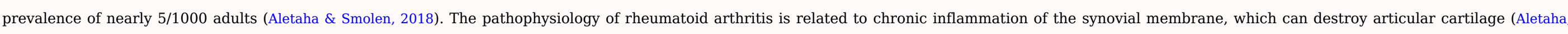
Funovits, Smolen, \& Editorial, 2011).

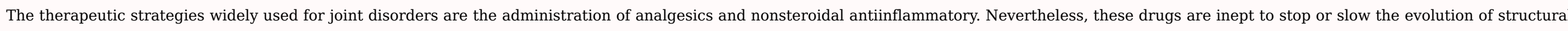

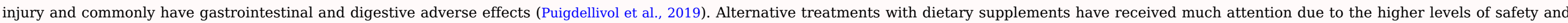
effectiveness.

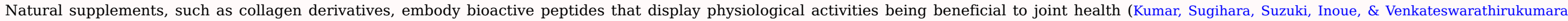

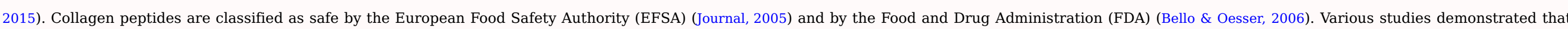

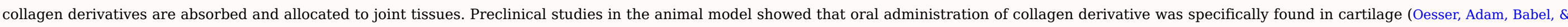

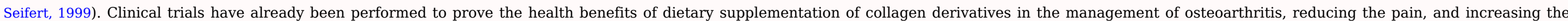

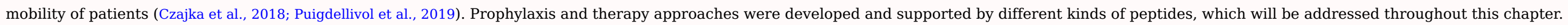




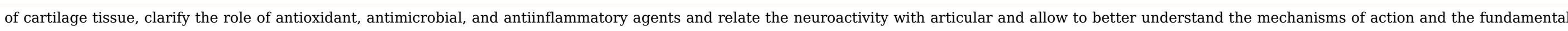

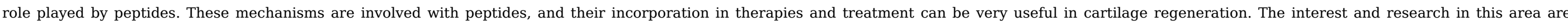

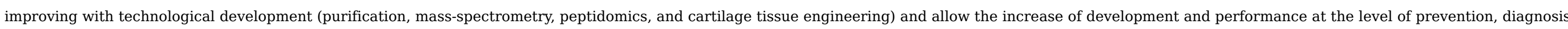
by biological markers, treatments, and therapeutics (Hu et al., 2020).

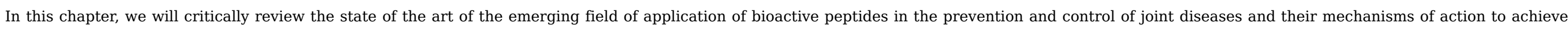
those benefits.

\subsection{Overview of joint diseases}

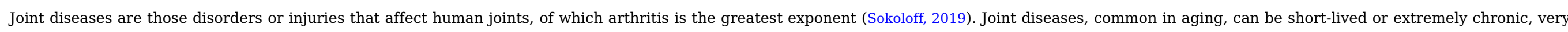

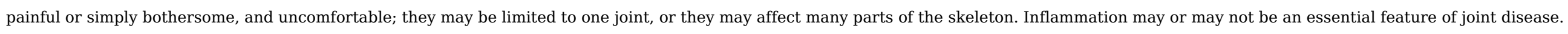

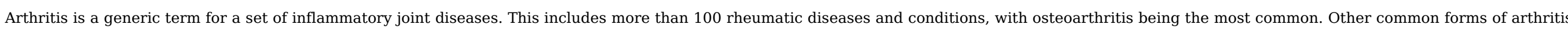

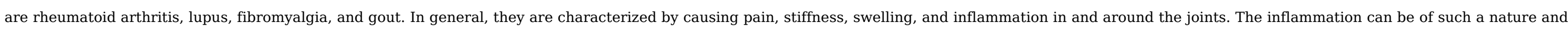

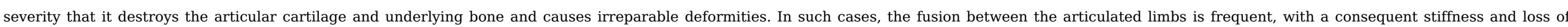
mobility (ankylosis). Some forms of arthritis, such as rheumatoid arthritis and lupus, can affect various organs and cause widespread symptoms (Sokoloff, 2019).

\subsubsection{Osteoarthritis}

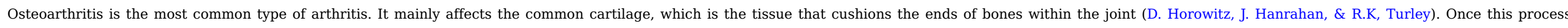

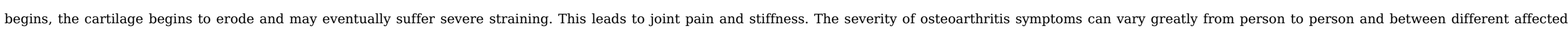
joints. In some cases, the symptoms may be mild and may be recurring. In other

Page 3

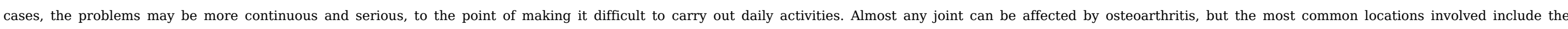
knees, hips, and small joints of the hands.

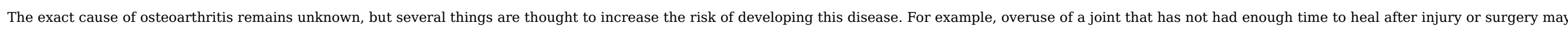

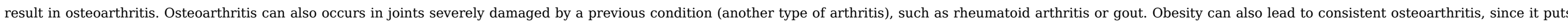

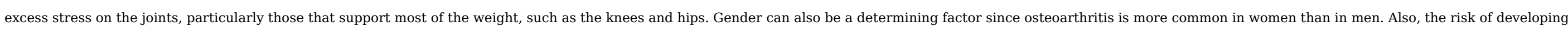
the condition increases with aging.

\subsubsection{Rheumatoid arthritis}

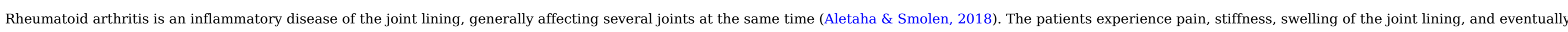

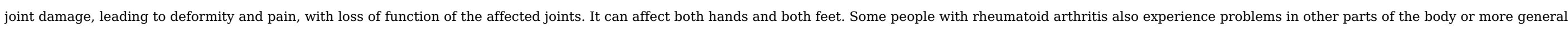
symptoms, such as tiredness and weight loss.

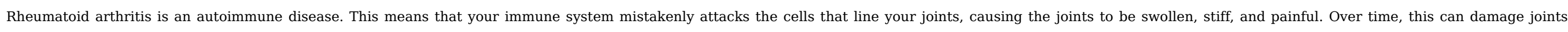
cartilage, and nearby bone. It is not clear what triggers this problem with the immune system, although an increased risk has been seen in women, smokers, or with family histories suffering this condition. 


\subsection{Peptides activity and characterization}

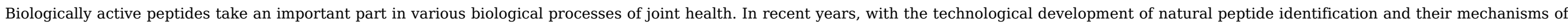

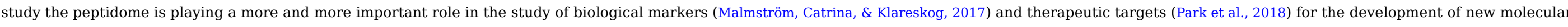
tools for the diagnosis, prevention, and therapy of joint diseases based on bioactive peptides.

\subsubsection{Natural bioactive peptide sources}

Collagen is one of the most abundant proteins in the world that is widely available and inexpensive to recover from animal (Fu, Therkildsen, Aluko, \& Lametsch, 2018; Silva et al., 2014)

Page 4

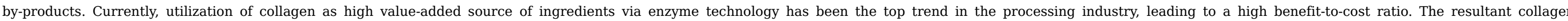

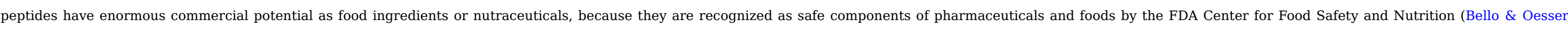

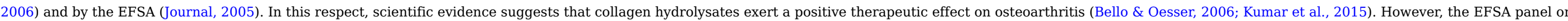

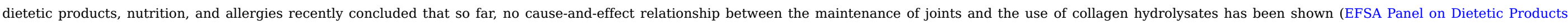

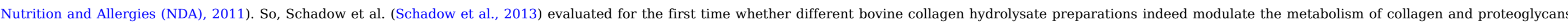

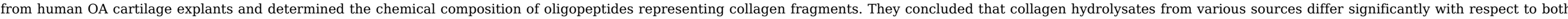

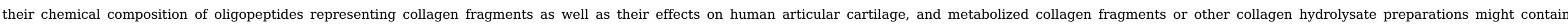

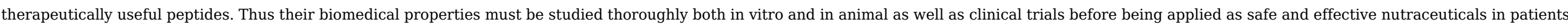

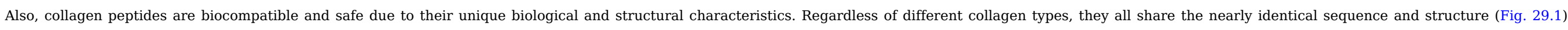

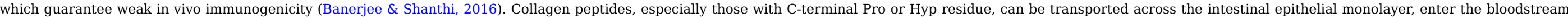

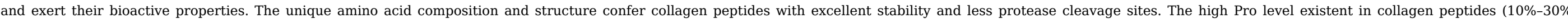

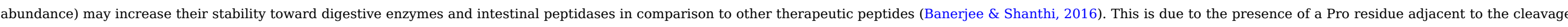

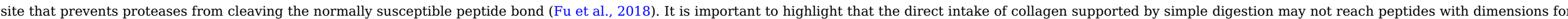

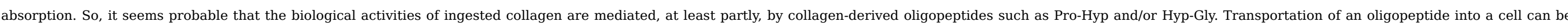
mediated by proton-coupled oligopeptide transporters that support low-molecular weight of peptides. 


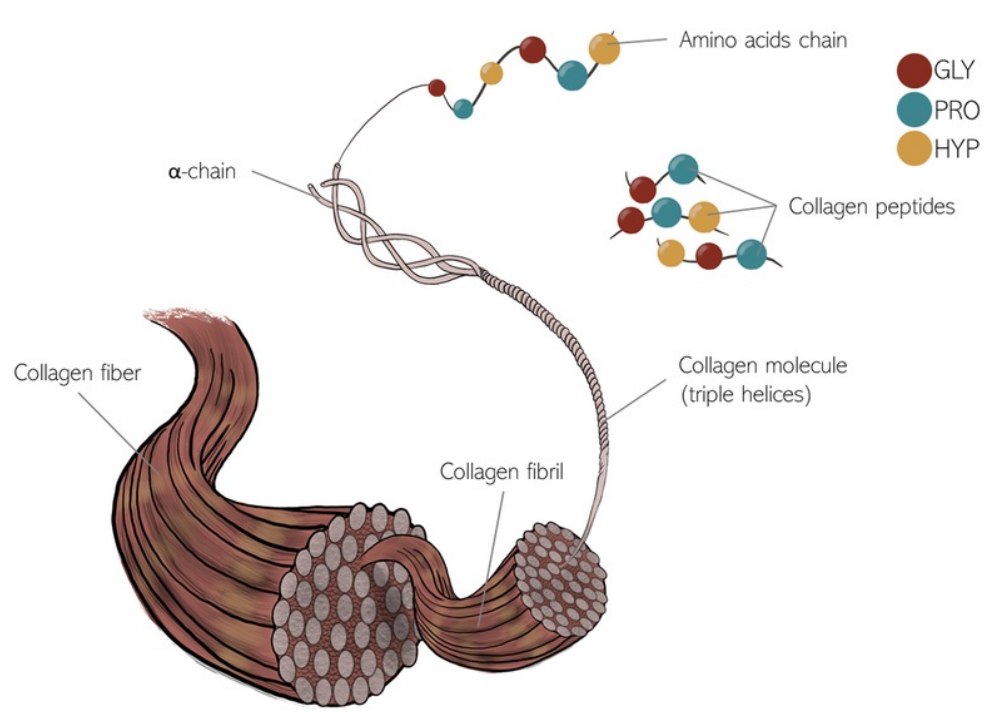

Figure 29.1 Raw collagen molecular structure and collagen peptides.

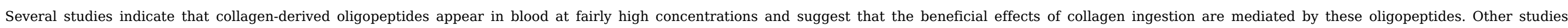
described the mechanism of absorption and distribution

Page 5

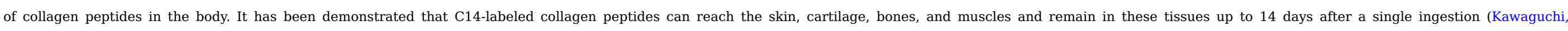

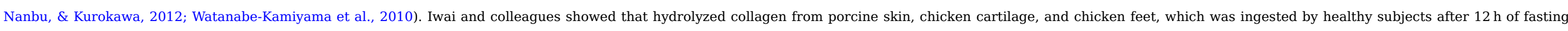

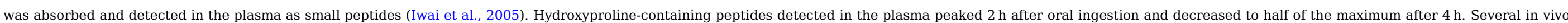
studies have demonstrated the efficacy of collagen peptides on skin and cartilage health and ageing (Czajka et al., 2018).

\subsubsection{Peptidome analysis}

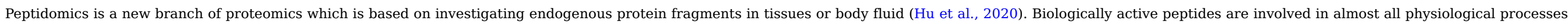
including cell differentiation, immune regulation, and even tumor formation (Ferro, Rioli, Castro, \& Fricker, 2014). So, the study of

bioactive peptides as biological markers and therapeutic targets for the diagnosis, prevention, and therapy of joint diseases is a very important research to be performed in the near future.

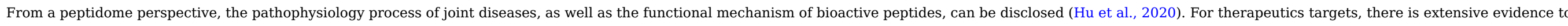

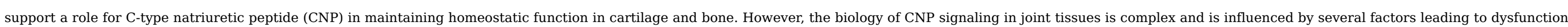




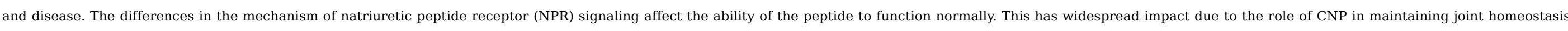

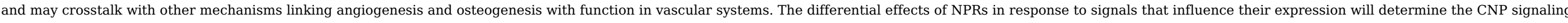

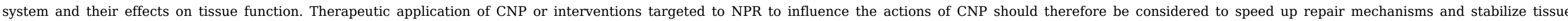

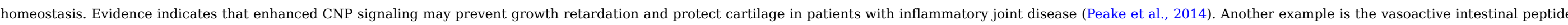

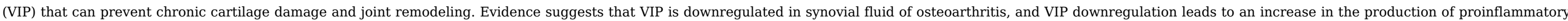
cytokines that might contribute to the pathogenesis of osteoarthritis (Jiang, Wang, Li, \& Luo, 2016).

\subsection{Mechanisms of action}

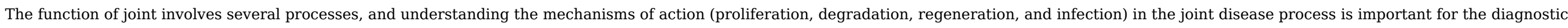

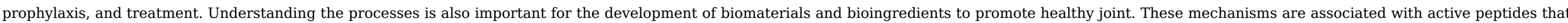
are involved in almost all physiological processes, including cell differentiation, proliferation, inflammatory process, and immune regulation (see Table 29.1).

Table 29.1 Endogenous and exogenous peptides with intervention in the function of joint.

\section{Protein/peptides}

TGF- $\beta$

BMPs

NF-K $\beta$ (RANKL)

SASP

CNP

Cytomodulins

NLS-TAT

E7, L7

HA-binding peptide

Chondroitin sulfate-binding peptide

RADA 16-1

KLD-12

RGD peptide

Collagen
Function/impact

References
Varela-Eirin et al. (2018)

Tuan et al. (2013)

Deng et al. (2018)

Parmar et al. (2015)

Peake et al. (2014)

Haque Bhuyan et al. (2017)

Faust et al. (2018)

Liu et al. (2018)

Dar et al. (2017)

Fish gelatine peptides 
TNF- $\alpha$

IL-1 $\beta$, IL-6, IL-10, IL-17A

5-LOX, 15-LOX

FPR2

Antimicrobial peptides (AMPs)

Lysozyme

Lactoferrin

Secretory phospholipase A2

RNase 7

CAP37

Cathelicidin LL37

HBD-2/-3
Antimicrobial peptides

Pinto et al. (2019)

Elezagic et al. (2019)

Varoga et al. (2005)
Neuroactivity
Al-Madol et al. (2017)

Janakiraman et al. (2018)

\section{VIP}

SP

CGRP

Jiang et al. (2016)

Kanemitsu et al. (2020)

Zhang et al. (2018)

Courties et al. (2017)

\subsubsection{Cartilage proliferation}

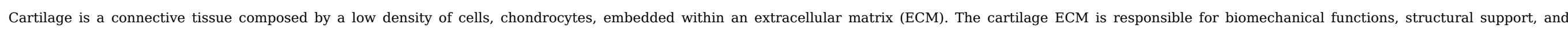
resistance to deformation. To ensure these mechanisms of action, various proteins and peptides are present, such as proteoglycans 


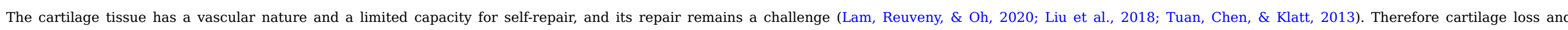
degeneration are often associated with

Page 8

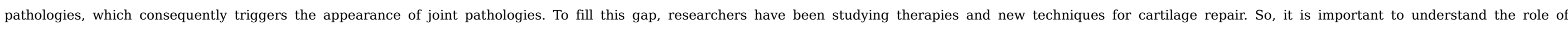
peptides in this process, because it can be promising in the proliferation and/or inhibition of cartilage degeneration.

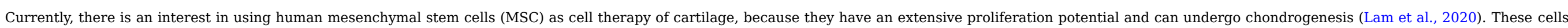

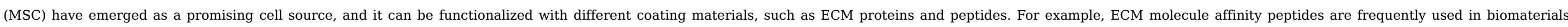
development, because they can help mimic the native environment of chondrocytes and influencing the biological functions of these molecules (Liu et al., 2018).

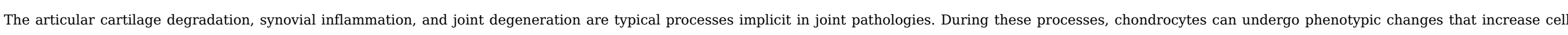

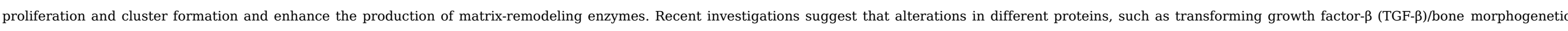

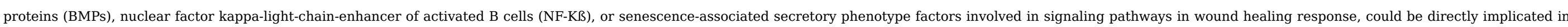

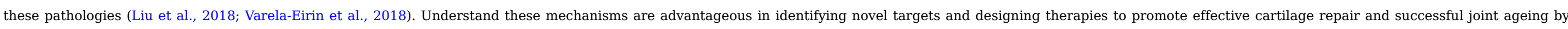
preventing functional limitations and disability (Varela-Eirin et al., 2018).

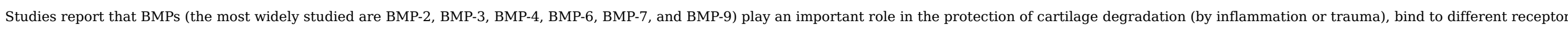

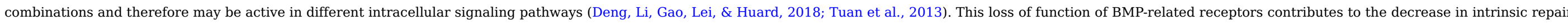

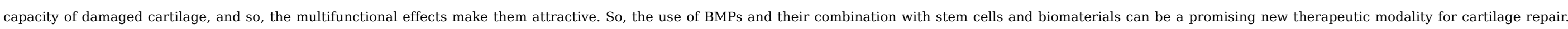

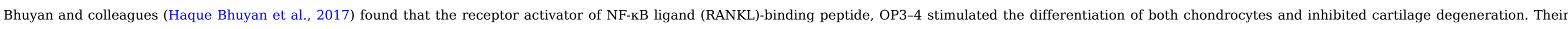

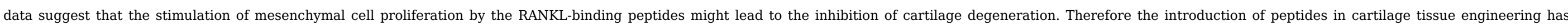
proven to be advantageous and is increasingly a solution in cartilage repair.

Other therapies/treatments have been developed with the aid of peptides, for example, the use of CNP has shown evidence for its ability to regulate cartilage and bone homeostasis.

Page 9

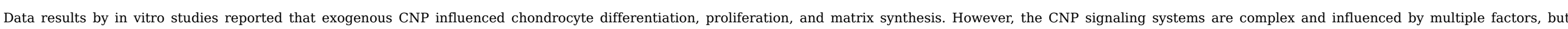

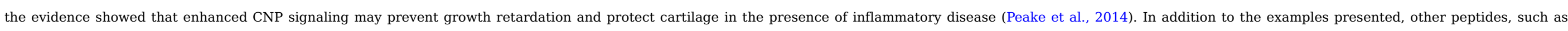
cytomodulins, NLS-TAT, E7, L7, TGFBP, and HA-binding peptide, chondroitin sulfate-binding peptide, RADA 16-1, KLD-12, and RGD peptide may also improve cartilage proliferation/repair (Liu et al., 2018).

\subsubsection{Antioxidant, antimicrobial, and antiinflammatory activities}

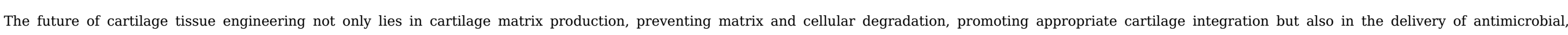

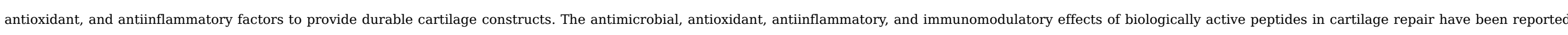
(see Table 29.1). 


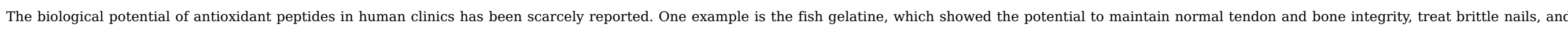
improve joint health (Kim \& Mendis, 2006).

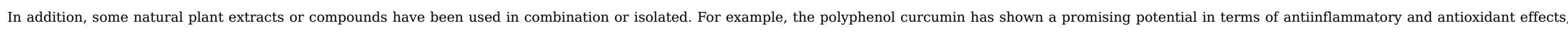

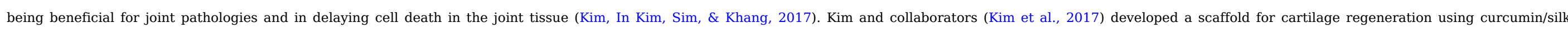
composite scaffold, and the results may provide clinical support for the patients with various cartilage diseases.

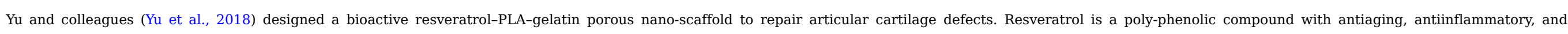
antioxidant functions. This bioactive molecule can alleviate damage to cartilage, as it can regulate inflammation signaling (PI3K/AKT signaling pathway) in human chondrocytes.

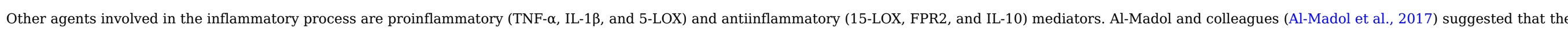

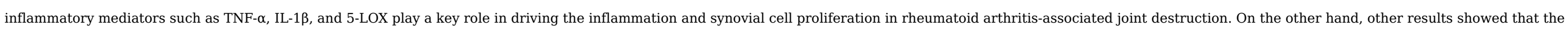

Page 10

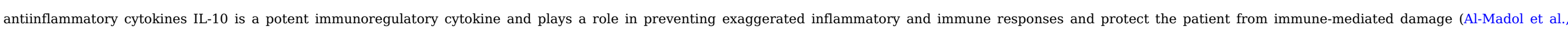

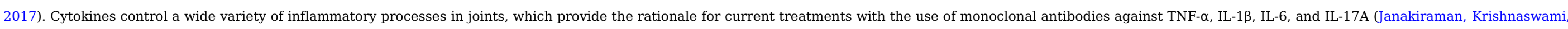

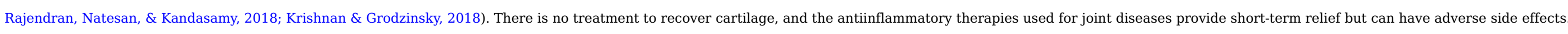

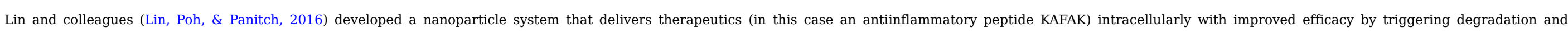

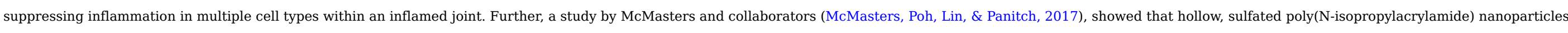
are an effective platform for the loading and delivery of antiinflammatory cell-penetrating peptides (KAFAK), with higher loading capacity, and prolonged-release profiles compared to other delivery systems.

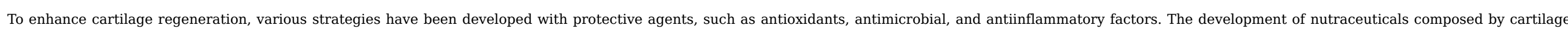

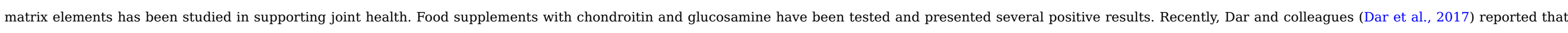

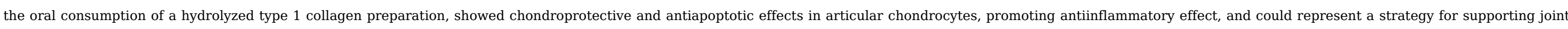
health.

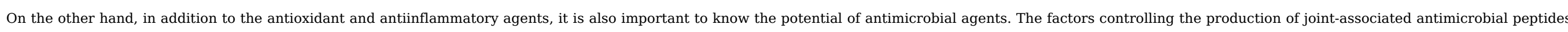

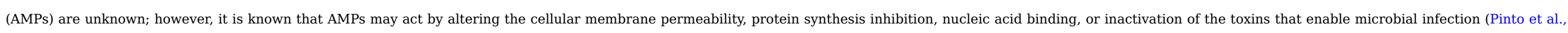

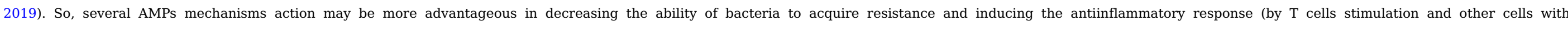

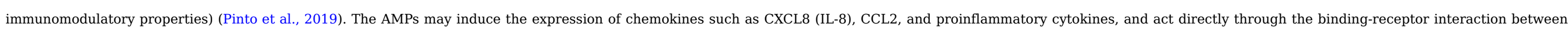
LL37 and formyl peptide receptor-like 1 (FPRL1) (Pinto et al., 2019). So, the bioinspired AMPs have become a promising alternative, namely for cartilage tissue regeneration

Page 11

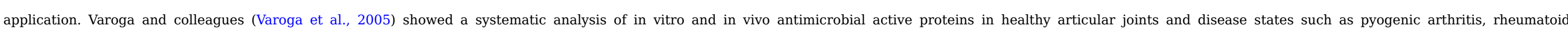

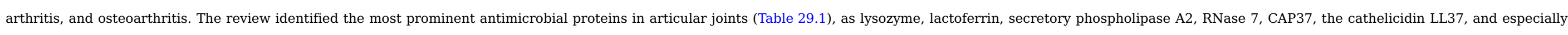

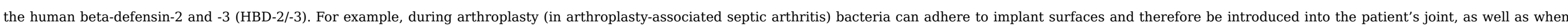




\subsubsection{Neuroactivity}

Joint diseases are associated with pain and despite therapeutics to pain control and the use of effective disease-modifying antirheumatic drugs, sometimes the pain persists.

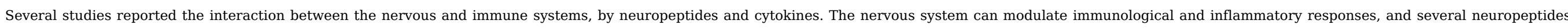

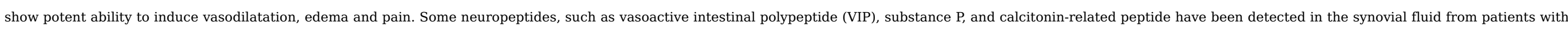
rheumatic disease.

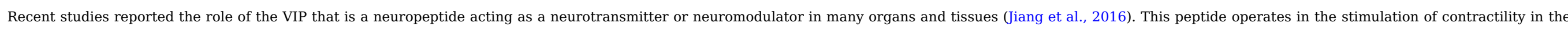

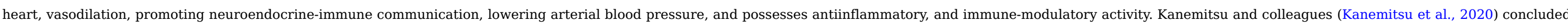
that the inhibition of VIP signaling has the potential to be a therapeutic target to prevent osteoarthritis progression.

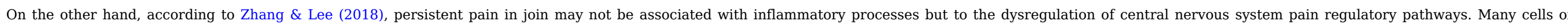

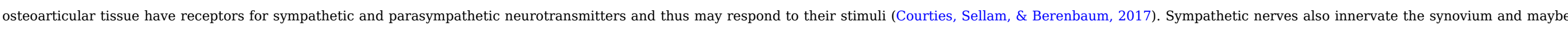

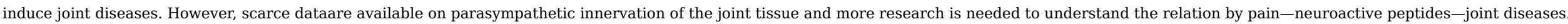

Page 12

\subsection{Evidence in joint health benefits}

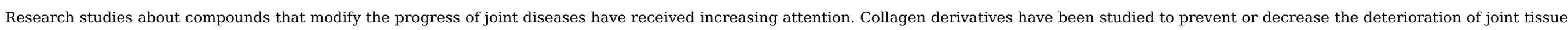

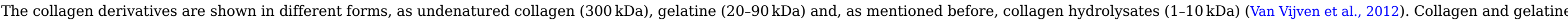

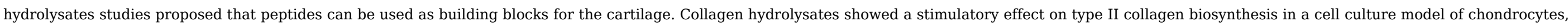

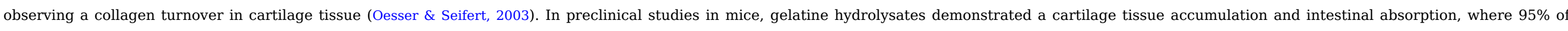
compounds were absorbed in the first $12 \mathrm{~h}$, observing its clinical benefit on degenerative diseases by oral administration (Oesser et al., 1999).

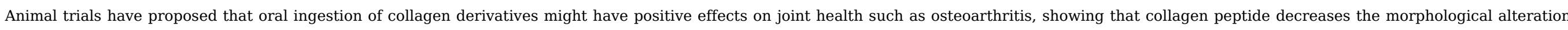

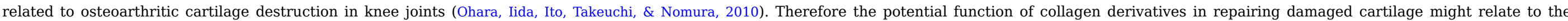
accumulation of orally administered collagen derivatives.

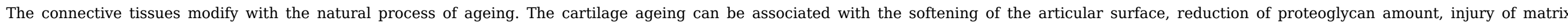

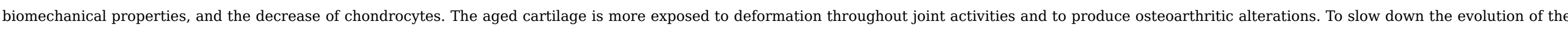

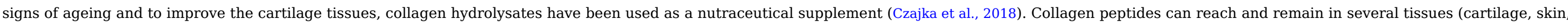

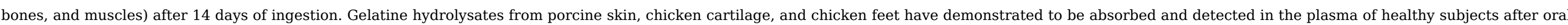

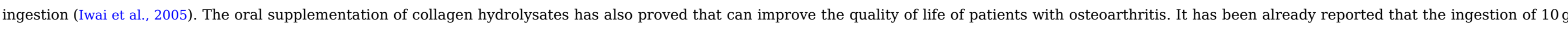

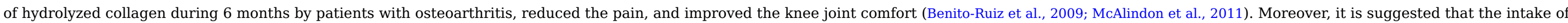

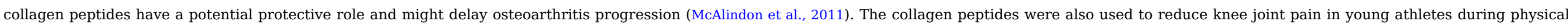
activity (Zdzieblik, Oesser, Gollhofer, \& König, 2017). Table 29.2 summarizes some of the randomized 
Table 29.2 Randomized controlled clinical trials of oral supplementation of collagen derivatives towards joint disorders.

\begin{tabular}{|c|c|c|c|c|}
\hline Intervention & Participants & $\begin{array}{l}\text { Follow- } \\
\text { up }\end{array}$ & Outcomes & Reference \\
\hline $\begin{array}{l}\text { Daily consumption of } 50 \mathrm{~mL} \text { of a test product with } 8 \% \text { of hydrolyzed } \\
\text { collagen from fish combined with vitamins and other compounds }\end{array}$ & $\begin{array}{l}122 \text { volunteer subjects } \\
\text { between } 21 \text { and } 70 \text { years } \\
\text { old }\end{array}$ & $\begin{array}{c}90 \\
\text { days }\end{array}$ & $\begin{array}{l}\text { Improvement of clinical parameters related to joint health, such as reduction of joint pain } \\
\text { by } 43 \% \text { and improvement of joint mobility by } 39 \%\end{array}$ & $\begin{array}{l}\text { Czajka et al. } \\
\quad(2018)\end{array}$ \\
\hline $\begin{array}{l}\text { Daily consumption of } 720 \mathrm{mg} \text { of promerim for the first } 15 \text { days and } \\
\text { then } 360 \mathrm{mg} \text { for the second } 15 \text { days. Promerim is a dietary } \\
\text { supplement that contains hydrolyzed fish collagen }\end{array}$ & $\begin{array}{l}92 \text { subjects between } 40 \text { and } \\
69 \text { years old with knee pain }\end{array}$ & $\begin{array}{c}1 \\
\text { month }\end{array}$ & Rapidly reduction of pain and stiffness in the knee osteoarthritis & $\begin{array}{l}\text { Kilinc et al. } \\
\text { (2018) }\end{array}$ \\
\hline $\begin{array}{l}\text { Daily consumption of eight tablets containing shark cartilage } \\
\text { extract ( } 45 \mathrm{mg} \text { of type II collagen peptides and } 60 \mathrm{mg} \text { chondroitin } \\
\text { sulfate), glucosamine hydrochloride, among other ingredients }\end{array}$ & $\begin{array}{l}100 \text { subjects between } 40 \\
\text { and } 74 \text { years old with knee } \\
\text { pain }\end{array}$ & $\begin{array}{c}16 \\
\text { weeks }\end{array}$ & Improvement of locomotor functions and relieve knee pain & $\begin{array}{l}\text { Kanzaki, } \\
\text { Ono, } \\
\text { Shibata, \& } \\
\text { Moritani } \\
\text { (2015) }\end{array}$ \\
\hline $\begin{array}{l}\text { Twice a day consumption of } 5 \mathrm{~g} \text { of test product dissolved in } 250 \mathrm{~mL} \\
\text { water or milk containing collagen peptides isolated from pork skin } \\
\text { or bovine bone }\end{array}$ & $\begin{array}{l}30 \text { subjects between } 30 \text { and } \\
65 \text { years old diagnosed with } \\
\text { knee osteoarthritis }\end{array}$ & $\begin{array}{c}91 \\
\text { days }\end{array}$ & $\begin{array}{c}\text { Improvement of the overall physical discomforts resulting from the osteoarthritis, such as } \\
\text { pain, stiffness, and physical functions }\end{array}$ & $\begin{array}{l}\text { Kumar et al. } \\
(2015)\end{array}$ \\
\hline $\begin{array}{l}\text { Consumption of a daily dose of } 40 \mathrm{mg} \text { of undenatured type II } \\
\text { collagen derived from chicken sternum }\end{array}$ & $\begin{array}{l}191 \text { subjects between } 40 \\
\text { and } 75 \text { years old with } \\
\text { moderate-to-severe } \\
\text { osteoarthritis }\end{array}$ & $\begin{array}{l}180 \\
\text { days }\end{array}$ & $\begin{array}{l}\text { Amelioration of knee joint symptoms, namely pain, stiffness and physical functions. } \\
\text { Undenatured type II collagen presented better clinical outcomes than glucosamine } \\
\text { hydrochloride plus chondroitin sulfate (widely available supplement used for reducing } \\
\text { joint pain) }\end{array}$ & $\begin{array}{l}\text { Lugo, } \\
\text { Saiyed, \& } \\
\text { Lane (2016) }\end{array}$ \\
\hline $\begin{array}{l}\text { Oral administration of one tablet three times per day, that } \\
\text { comprises mainly hydrolyzed gelatine ( } 500 \mathrm{mg} / \text { tablet), chondroitin } \\
\text { sulfate, glucosamine sulfate, and devil's claw and bamboo extracts }\end{array}$ & $\begin{array}{l}130 \text { subjects aged } \geq 18 \\
\text { years with osteoarthritis }\end{array}$ & $\begin{array}{l}180 \\
\text { days }\end{array}$ & $\begin{array}{l}\text { Nutritional supplement reduced articular pain and improved locomotor function of the } \\
\text { knee and/or hip }\end{array}$ & $\begin{array}{l}\text { Puigdellivol } \\
\text { et al. (2019) }\end{array}$ \\
\hline A daily dose of $5 \mathrm{~g}$ of collagen peptides & $\begin{array}{l}160 \text { athletic subjects } \\
\text { between } 18 \text { and } 30 \text { years } \\
\text { old }\end{array}$ & $\begin{array}{c}12 \\
\text { weeks }\end{array}$ & $\begin{array}{c}\text { Supplementation of collagen derivative led to an improvement of activity-related joint } \\
\text { pain in a young adult with functional knee problems }\end{array}$ & $\begin{array}{l}\text { Zdzieblik et } \\
\text { al. (2017) }\end{array}$ \\
\hline
\end{tabular}

\subsection{Potential applications, production, and commercialization \\ 29.6.1 Diagnostic}

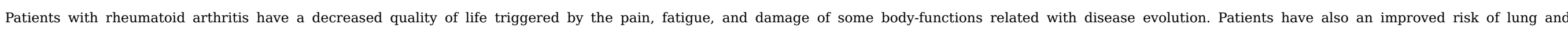

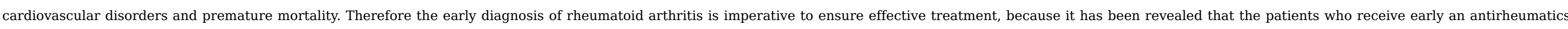

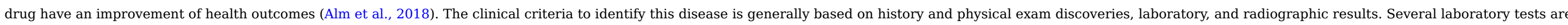

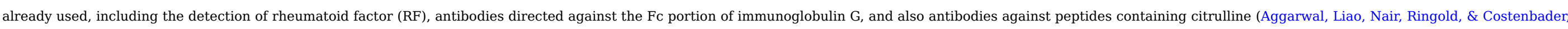

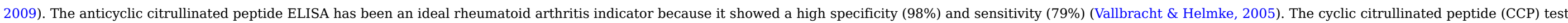

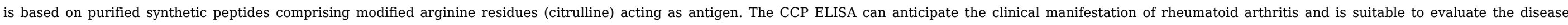




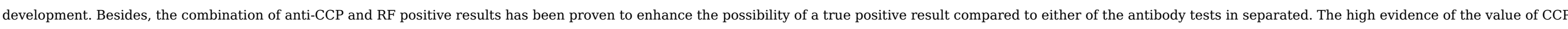
assays for the diagnosis of rheumatoid arthritis led to the integration of this test in the American College of Rheumatology guidelines (Alm et al., 2018).

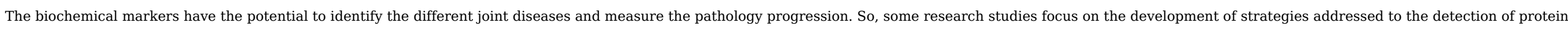
fragments that are generated in joint

Page 15

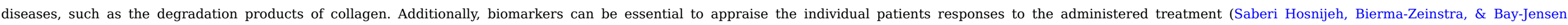
2019).

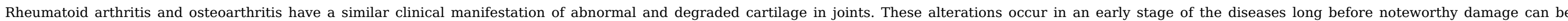

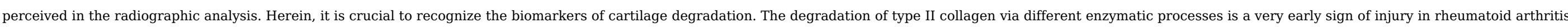

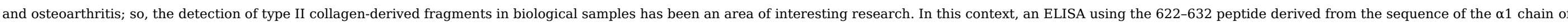

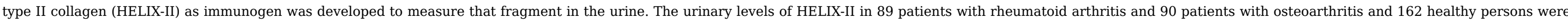
measured. The HELIX-II ELISA showed to be a useful noninvasive assay to distinguish patients with rheumatoid arthritis or osteoarthritis from healthy people (Charni, Juillet, \& Garnero, 2005).

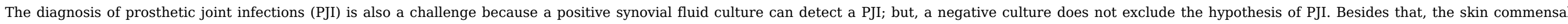

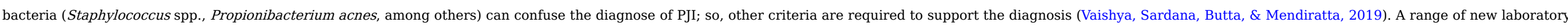

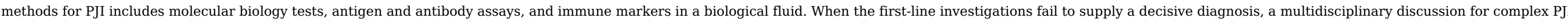

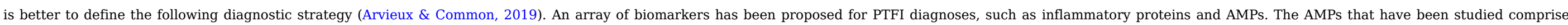

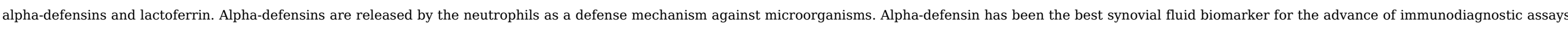
(Vaishya et al., 2019). This test is not affected by antibiotherapy or inflammatory conditions. The alpha-defensin PJI assay revealed high specificity (100\%) and sensitivity (92.1\%) (Hosny \& Keenan, 2020).

\subsubsection{Prophylaxis/therapeutic}

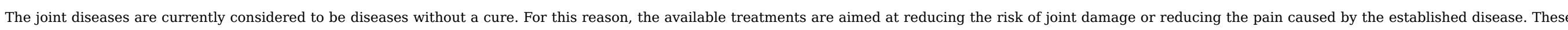
disorders are mostly treated through exercise

Page 16

combined with the administration of analgesics or nonsteroidal antiinflammatory drugs. These drugs are for symptoms relief but do not alter the disease and still cause adverse effects.

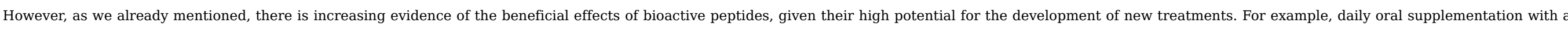

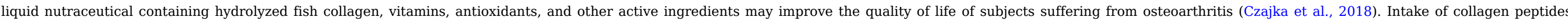

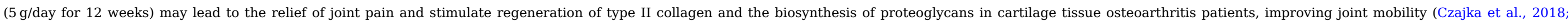
McAlindon et al., 2011; Zdzieblik et al., 2017).

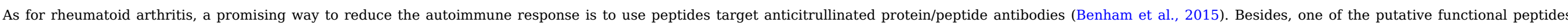




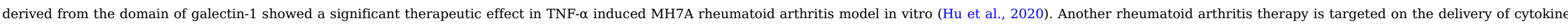
therapy to rheumatoid tissue by a synovial targeting peptide (Wythe et al., 2013).

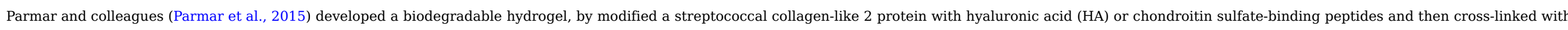

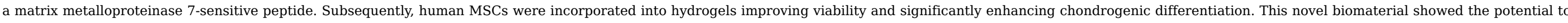
act in cell-mediated processes and improve the cartilage repair.

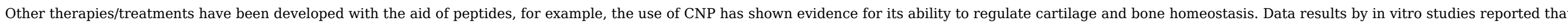

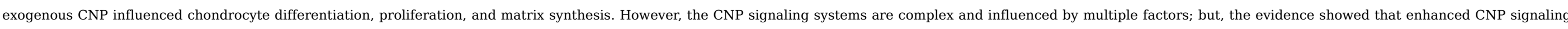
may prevent growth retardation and protect cartilage in the presence of inflammatory disease (Peake et al., 2014).

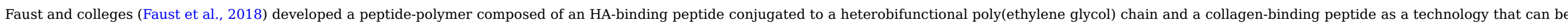

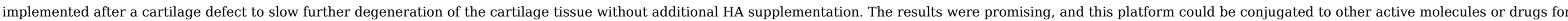
targeted delivery to damaged areas of cartilage in vivo. However, more studies are needed to validate their therapeutic efficacy

Page 17

Even some studies have been performed, it is considered that the evidence is not enough and that a larger critical mass of human studies is necessary to get a correct validation of all the findings.

\subsubsection{Production and commercialization}

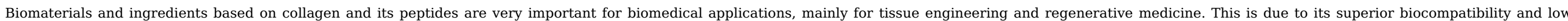
immunogenicity, always depending on the sources from which the collagen is taken (Silva et al., 2014)

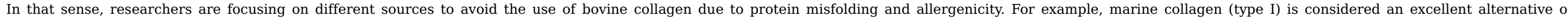

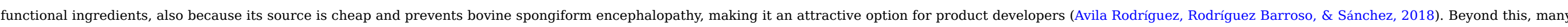

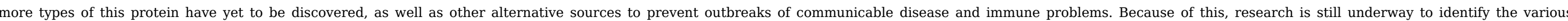
unexplored sources of collagen that may be used in the future.

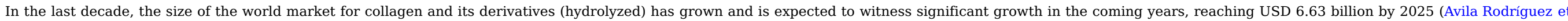

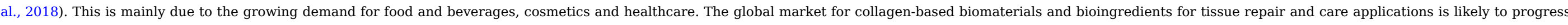
to a solid compound annual growth rate of $10.4 \%$ over the next 5 years (Avila Rodríguez et al., 2018).

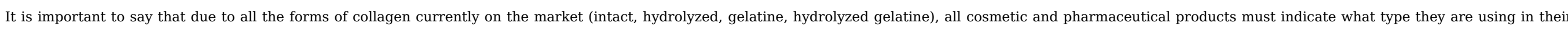

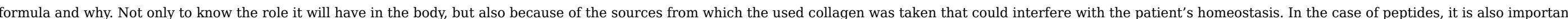
to know if the hydrolysis was chemical or enzymatic, as well as the size profile of the peptides since their bioactivity depends on it (Coscueta, Campos, Osório, Nerli, \& Pintado, 2019)

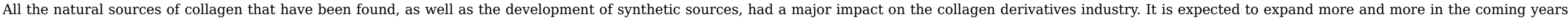
thus opening new strong and interesting opportunities in the field of research applicable to the biomedical industry whose main application is in the prophylaxis and treatment of joints. 


\subsection{Summary}

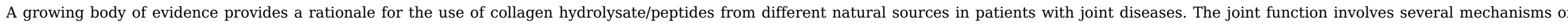

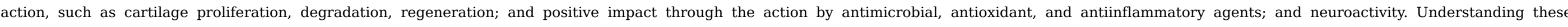

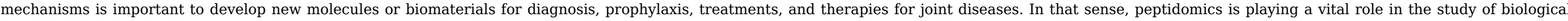

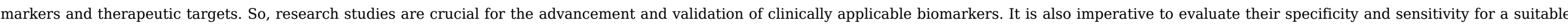

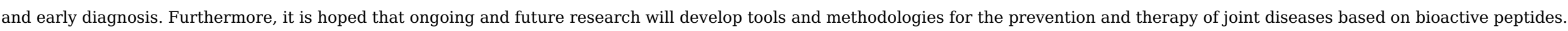

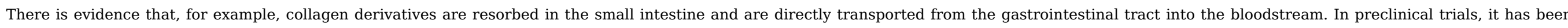

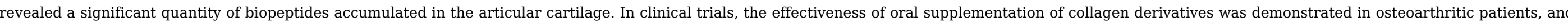

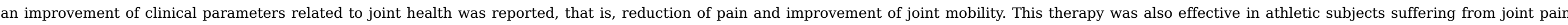
related to excessive physical activity.

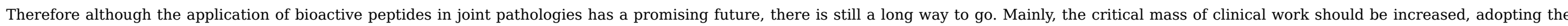
new strategies developed in real cases.

\section{Acknowledgments}

This work was supported by National Funds from FCT-Fundação para a Ciência e a Tecnologia through project UID/Multi/50016/2019.

\section{References}

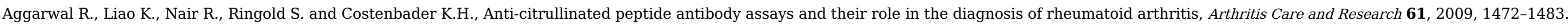

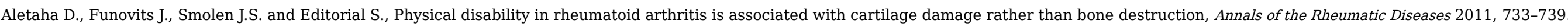
https://doi.org/10.1136/ard.2010.138693.

Aletaha D. and Smolen J.S., Diagnosis and management of rheumatoid arthritis: A review, JAMA: The Journal of the American Medical Association 320, $2018,1360-1372$.

Page 19

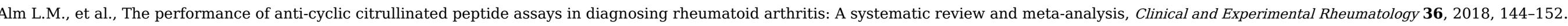

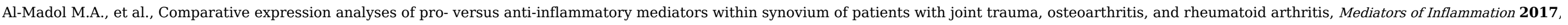
2017.

Arvieux C. and Common H., New diagnostic tools for prosthetic joint infection, Orthopaedics and Traumatology: Surgery and Research 105, 2019, S23-S30.

Avila Rodríguez M.I., Rodríguez Barroso L.G. and Sánchez M.L., Collagen: A review on its sources and potential cosmetic applications, Journal of Cosmetic Dermatology 17, 2018, 20-26.

Banerjee P. and Shanthi C., Cryptic peptides from collagen: A critical review, Protein and Peptide Letters 23, 2016, 664-672.

Bello A.E. and Oesser S., Collagen hydrolysate for the treatment of osteoarthritis and other joint disorders: A review of the literature, Current Medical Research and Opinion 22, $2006,2221-2232$.

Benham H., et al., Citrullinated peptide dendritic cell immunotherapy in HLA risk genotype-Positive rheumatoid arthritis patients, Rheumatoid arthritis 7, 2015. 


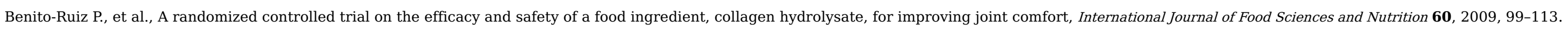

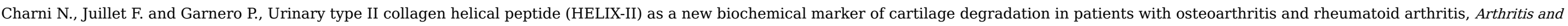
Rheumatism 52, 2005, 1081-1090.

Coscueta E.R., Campos D.A., Osório H., Nerli B.B. and Pintado M., Enzymatic soy protein hydrolysis: A tool for biofunctional food ingredient production, Food Chemistry: X 1, 2019, 100006.

Courties A., Sellam J. and Berenbaum F., Role of the autonomic nervous system in osteoarthritis, Best Practice and Research: Clinical Rheumatology 31, 2017 , 661-675.

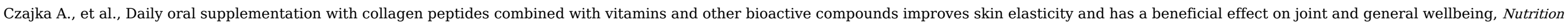
Research (New York, N.Y.) 57, 2018, 97-108.

Dar Q.-A.A., et al., Daily oral consumption of hydrolyzed type 1 collagen is chondroprotective and anti-inflammatory in murine posttraumatic osteoarthritis, PLoS One 12, 2017 , e0174705.

Deng Z.H., Li Y.S., Gao X., Lei G.H. and Huard J., Bone morphogenetic proteins for articular cartilage regeneration, Osteoarthritis and Cartilage 26, $2018,1153-1161$.

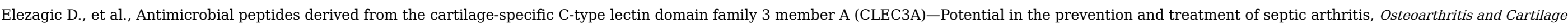
27, 2019, 1564-1573.

Faust H.J., et al., A hyaluronic acid binding peptide-polymer system for treating osteoarthritis, Biomaterials 183, 2018, 93-101.

Ferro E.S., Rioli V., Castro L.M. and Fricker L.D., Intracellular peptides: From discovery to function, EuPA Open Proteomics 3, 2014, $143-151$.

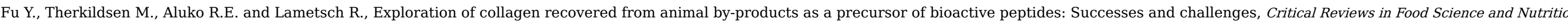
8398, 2018

Fusco M., Skaper S.D., Coaccioli S., Varrassi G. and Paladini A., Degenerative Joint diseases and neuroinflammation, Pain Practice 17, $2017,522-532$.

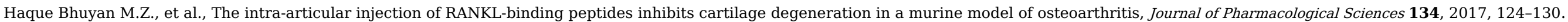

Hosny H.A. and Keenan J., Management of prosthetic joint infection, Surgery (United Kingdom) 38, 2020, 114-120.

Hu J., et al., Peptidomic analysis on synovial tissue reveals galectin-1 derived peptide as a potential bioactive molecule against rheumatoid arthritis, Cytokine 131, $2020,155020$.

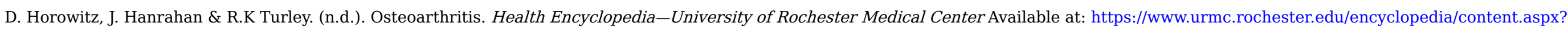
contenttypeid $=85 \&$ contentid $=$ p00061.

Page 20

Iwai K., et al., Identification of food-derived collagen peptides in human blood after oral ingestion of gelatin hydrolysates, Journal of Agricultural and Food Chemistry 53, 2005, 6531-6536.

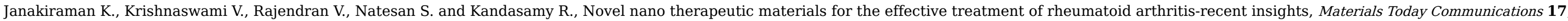
2018, 200-213.

Jiang W., Wang H., Li Y.S. and Luo W., Role of vasoactive intestinal peptide in osteoarthritis, Journal of Biomedical Science 23, 2016, 1-6.

EFSA Journal. (2005). Undefined. Opinion of the Food Safety Authority on safety of collagen and a processing method for the production of collagen. 


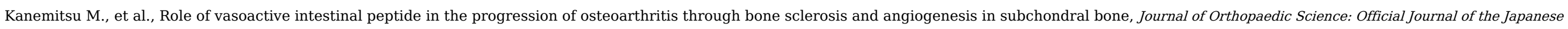
Orthopaedic Association 2020. https://doi.org/10.1016/j.jos.2019.11.010.

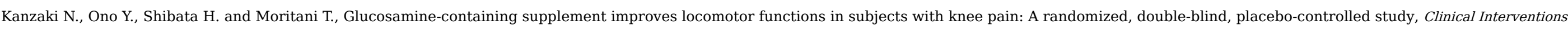
in Aging 10, 2015, 1743-1753.

Kawaguchi T., Nanbu P.N. and Kurokawa M., Distribution of prolylhydroxyproline and its metabolites after oral administration in rats, Biological \& Pharmaceutical Bulletin 35, 2012 , $422-427$.

Kilinc B.E., et al., An observational 1-month trial on the efficacy and safety of promerim for improving knee joint, Clinical Medicine Insights: Arthritis and Musculoskeletal Disorders 11, 2018.

Kim D.K., In Kim J., Sim B.R. and Khang G., Bioengineered porous composite curcumin/silk scaffolds for cartilage regeneration, Materials Science and Engineering C 78, 2017, 571-578.

Kim S.K. and Mendis E., Bioactive compounds from marine processing byproducts-A review, Food Research International 39, 2006, $383-393$.

Krishnan Y. and Grodzinsky A.J., Cartilage diseases, Matrix Biology 71-72, 2018, 51-69.

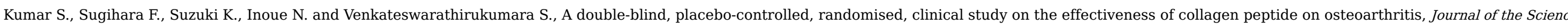
of Food and Agriculture 95, 2015, 702-707.

Lam A.T.L., Reuveny S. and Oh S.K.W., Human mesenchymal stem cell therapy for cartilage repair: Review on isolation, expansion, and constructs, Stem Cell Research 44, $2020,101738$.

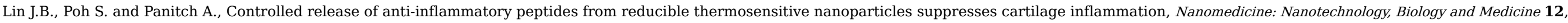
2016, 2095-2100.

Liu Q., et al., Functional peptides for cartilage repair and regeneration, American Journal of Translational Research 10, 2018, 501-510.

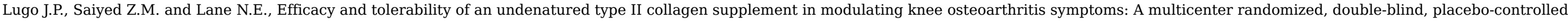
study, Nutrition Journal 15, 2016, 1-15.

Malmström V., Catrina A.I. and Klareskog L., The immunopathogenesis of from triggering to targeting, Nature Reviews. Immunology 17, $2017,60-75$.

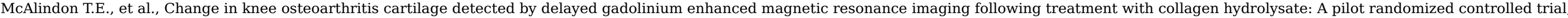
Osteoarthritis and Cartilage 19, 2011, 399-405.

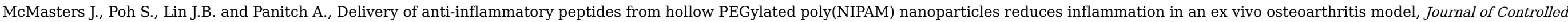
Release: Official Journal of the Controlled Release Society 258, 2017, 161-170.

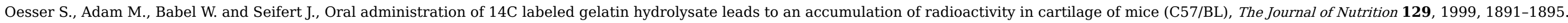

Oesser S. and Seifert J., Stimulation of type II collagen biosynthesis and secretion in bovine chondrocytes cultured with degraded collagen, Cell and Tissue Research 311, 2003, 393-399.

Page 21

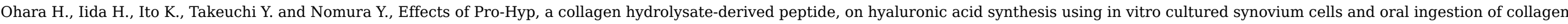
hydrolysates in a guinea pig model of osteoarthritis, Bioscience, Biotechnology, and Biochemistry 74, 2010, 2096-2099.

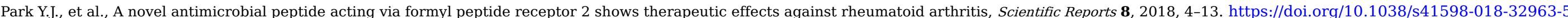


Parmar P.A., et al., Collagen-mimetic peptide-modifiable hydrogels for articular cartilage regeneration, Biomaterials 54, 2015, $213-225$.

Peake N.J.J., et al., Role of C-type natriuretic peptide signalling in maintaining cartilage and bone function, Osteoarthritis and Cartilage 22, $2014,1800-1807$.

Pinto I.B., et al., Utilization of antimicrobial peptides, analogues and mimics in creating antimicrobial surfaces and bio-materials, Biochemical Engineering Journal 150, 2019 , 107237.

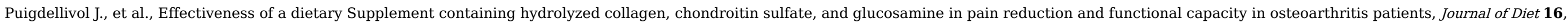
2019, 379-389.

Saberi Hosnijeh F., Bierma-Zeinstra S.M. and Bay-Jensen A.C., Osteoarthritis year in review 2018: Biomarkers (biochemical markers), Osteoarthritis and Cartilage 27, 2019, 412-423.

Schadow S., et al., Collagen metabolism of human osteoarthritic articular cartilage as modulated by bovine collagen hydrolysates, PLoS One 8, 2013.

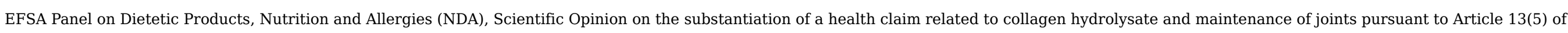
Regulation (EC) No 1924/2006, EFSA Journal 9, 2011.

Silva T.H., et al., Marine origin collagens and its potential applications, Marine Drugs 12, 2014, 5881-5901.

Sokoloff L., Joint disease, Encyclopædia Britannica 2019, Available at. https://www.britannica.com/science/joint-disease.

Tuan R.S., Chen A.F. and Klatt B.A., Cartilage regeneration, Journal of the American Academy of Orthopaedic Surgeons 21, 2013, 303-311.

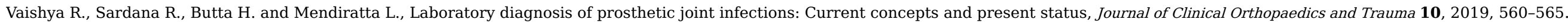

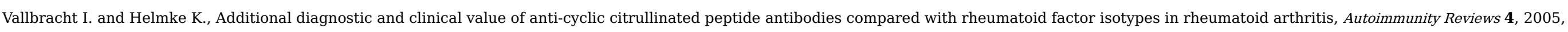
389-394.

Varela-Eirin M., et al., Cartilage regeneration and ageing: Targeting cellular plasticity in osteoarthritis, Ageing Research Reviews 42, 2018 , 56-71.

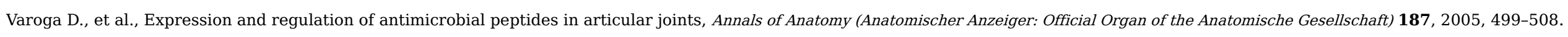

Van Vijven J.P.J., et al., Symptomatic and chondroprotective treatment with collagen derivatives in osteoarthritis: A systematic review, Osteoarthritis and Cartilage 20, 2012 , 809-821.

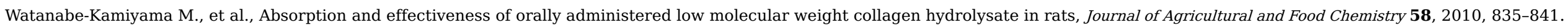

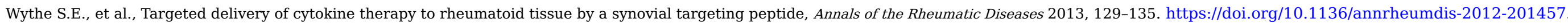

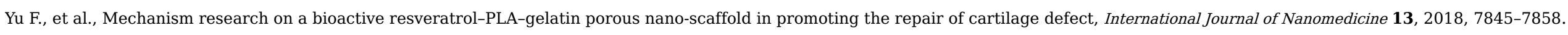

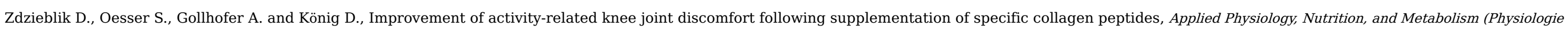
Appliquee, Nutrition et Metabolisme) 42, 2017, 588-595.

Zhang A. and Lee Y.C., Mechanisms for joint pain in rheumatoid arthritis (RA): From cytokines to central sensitization, Current Osteoporosis Reports 16, 2018, 603-610.

Zhang Y., et al., Soy peptide nanoparticles by ultrasound-induced self-assembly of large peptide aggregates and their role on emulsion stability, Food Hydrocolloids 74, 2018 , 62-71.

Abstract

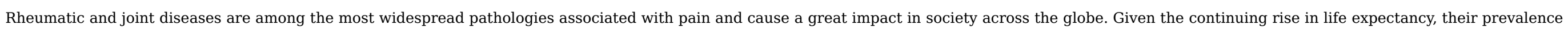

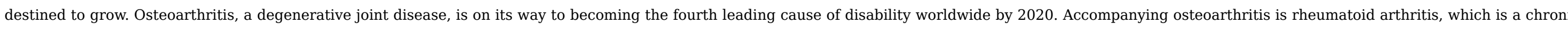

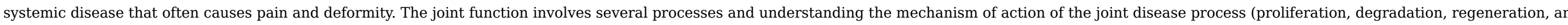

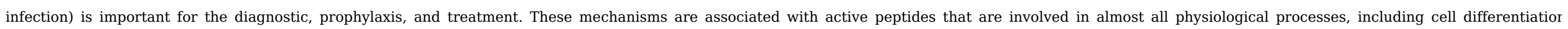




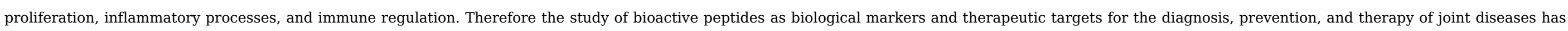

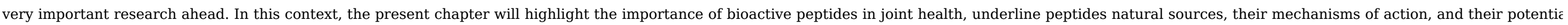
applications on joint diseases.

Keywords: Joint health; osteoarthritis; rheumatoid arthritis; collagen peptides; biological markers; therapeutics targets

\section{Queries and Answers}

Query: Please check the chapter title and correct if necessary.

Answer: The title is correct.

Query: Please check the author group and correct if necessary.

Answer: The author group names are correct. 